\title{
EFFECT OF EVAPORATIVE COOLING SYSTEM ON MICROCLIMATIC CIRCUMSTANCES OF COMMERCIAL CLOSED LAYING-HENS HOUSE UNDER DELTA-ZONE CLIMATIC CONDITIONS
}

\author{
Darwesh, M.R *
}

\begin{abstract}
High temperature gradients can markedly affect laying hen's growth development, productivity, health and welfare of the birds. This research work was conducted to investigate the feasibility of using direct evaporative cooling to improve the indoor air conditions in a laying-hens house. In this present study trail, a laying-hens house of $460 \mathrm{~m}^{2}$ floor surface area was tested under climatic conditions of eastern area of coastal Delta, Egypt (latitude angle of $31.05^{\circ} \mathrm{N}$, longitude angle of $31.37^{\circ} \mathrm{E}$, and mean altitude above sea level of $14 \mathrm{~m}$ ). Experiments were performed through three summer months of 2014 (from June to August) for laying-hens chickens at 150 days of age. Three different water flow rates (60, 70 and $80 \mathrm{l} / \mathrm{min})$ were examined during the experimental work to determine the best one can be compensated the high air temperature occurred inside the housing. In order to achieve that, different measurements were accomplished in a commercial closed house of laying hens equipped with a complete evaporative cooling system (fanpad system). Cooling effect (CE), cooling efficiency $(\eta)$, temperature humidity index (THI), vapor pressure deficit (VPD), rate of heat energy removal from the laying hen's house $(Q)$, total amount of moisture addition to the saturated air after cooling by evaporative process (W) and both of bird's body weight and production egg rate were computed during the experimental period. Experimental data revealed that the evaporative cooling system was able and adequate to keep and maintain the indoor air temperature of laying hens housing at desired level. The obtained results also clarified that the daily average cooling efficiency during June, July and August, was determined as 77.4\%, 75.6\% and $79.5 \%$, respectively. Accordingly, the indoor dry- bulb temperature lowered between $7.1-8.5^{\circ} \mathrm{C}$ with $30-40 \%$ rise in air relative humidity.
\end{abstract}

* Lecturer, Agric. Eng. Dept., Faculty of Agric., Tanta University 


\section{INTRODUCTION}

The poultry industry in Egypt has been revolutionized since the last five decades including; the production of eggs through laying

hens and white meat through broiler. The egg is considered one of the most important sources for protein that can directly eat or enters in some food industrialization.

The thermal comfortable zone (indoor air temperature) for laying hens is, about $25^{\circ} \mathrm{C}$ around the birds in their housing. At indoor air temperatures below this there is a depression of about 0.5 egg per hen housed per year per $0.5^{\circ} \mathrm{C}$. Obviously such low indoor air temperature cannot be provided and maintained in summer but this is compensated for by increasing the ventilation and air velocity or using the evaporative cooling system. If the indoor air temperature rises above $25^{\circ} \mathrm{C}$ for lengthy periods as in summer months (the outdoor air temperature ranged from $30^{\circ} \mathrm{C}$ to $38^{\circ} \mathrm{C}$ during daylight), the total number of eggs laid and their weight and quality certainly suffer (Sainsbury and Sainsbury, 2003). Birds may frequently suffer heat stress, which reduces feed consumption, weight gain, and egg yield. Therefore, environmental control in laying hens houses can affect the rate of egg yield. For these reasons, different cooling systems have been developed to reduce indoor air temperature and alleviate heat stress of the birds during the summer. The evaporative cooling based on fan-pad system is widely used in livestock and poultry housings in regions with hot and dry conditions (Liao and Chiu, 2002).

Reducing indoor air temperatures is one of the main problems facing poultry housing management in warm and hot climates. One of the most efficient ways to reduce the difference between day and night air temperatures is the ventilation system. Natural or passive ventilation system uses very little external energy as opposed to active or forced ventilation, but it increases the complexity of house structure and makes climate control more difficult. Various technical equipments can efficiently contribute to maintain poultry housing indoor air temperature and relative humidity at desired levels during hot periods such as evaporative cooling system. However, adequate models may be 
necessary to estimate the cooling loads and adequately manage such climate control equipment. The principle of evaporative cooling reveals that the evaporative cooling system can only remove room sensible heat; therefore, the evaporative system works in finest in hot and dry climate where the maximum evaporative cooling will result (Chung et al., 2010).

Evaporative cooling is an adiabatic saturation process (no heat gained or lost) and follows upward along a constant wet-bulb temperature line. Air to be cooled is brought in contact with water at a temperature equal to the wet-bulb temperature of the air. The sensible heat of the initial air evaporates the water, lowering the dry-bulb temperature of that air. Sensible heat is converted into latent heat in the added vapour, so the process is adiabatic. Evaporative cooling process is most effective in hot dry climatic conditions where the wet-bulb depression (difference between dry-bulb and wet-bulb temperatures of the hot air) is large (ASHRAE, 2005).

Evaporative cooling is one alternative to mechanical vapour compression for air conditioning application. These systems usually require only a quarter of the electric power that mechanical vapour compression uses for air conditioning (Cerci, 2003). Therefore, such systems will help to reduce electricity requirements, and contribute to reducing building gas emission. Conventional evaporative cooling system can decrease the process air temperature theoretically approaching its wet-bulb temperature. Also, has been used as a low energy consuming device for various cooling and air conditioning applications in industrial, agricultural, and residential sectors (Goshayshi, et al., 1999; Maheshwari, et al., 2001; Costelloea and Finn, 2003; Sethi and Sharma, 2007) for providing low temperature medium fluid (i.e. air, water, etc.).

The efficiency of evaporative pad cooling systems can reach over $80 \%$ in hot and dry conditions (Kittas et al., 2003). Cruz et al. (2006) found that air temperature was reduced from 39 to $27^{\circ} \mathrm{C}$ by an evaporative pad cooling system. Dağtekin et al. (2009) used pad evaporative cooling systems to provide a solution for controlling the high temperatures that 
can negatively affect poultry houses. They found that average evaporative cooling efficiency ranged from $69.8 \%$ to $72 \%$ on July and August months, respectively. In addition, the temperature reduction was determined $5.7^{\circ} \mathrm{C}$ on July to $5.9^{\circ} \mathrm{C}$ on August. The procedure of evaporative cooling has been used to improve human, plant and animals comfort conditions for the long time in the thermal environmental control applications. It remains one of the least exclusive techniques to get drybulb temperature to a more comfortable range. Evaporative cooling has also many practical applications in agriculture. It has been become average for many poultry houses and greenhouses and is used for sheep and dairy cattle.

Many factors affecting evaporative cooling systems using fan-pad system such as pad material; pad thickness, pad face air velocity; weather conditions and water flow rate that dropped on pad. Cooling effect; saturation efficiency (SE); temperature-humidity index (THI) and heat absorption from system can be governed the system is sufficient or not (Liao and Chiu, 2002; Pierre et al, 2003 and Darwesh et al, 2009). The water flow rate, which dropped on pad system, is a parameter will be concentrated in this study because it associated with the ability of fan-pad system for absorbing and evaporating the water to accomplish the evaporation process. (Dzivama et al., 1999) indicated that the saturation efficiency is increased with the increase of the water flow rate until the pad is sufficiently moist. Meanwhile, Gunhan et al. (2007) evaluated the effects of the water flow rate on the evaporative saturation efficiency of pad materials in the air conditioning chamber 3 by 3 by $6 \mathrm{~m}$. They found that there is no significant effect of the water flow rate when used (1.00, $1.25,1.50$ and $1.751 / \mathrm{min}$ ) in this chamber.

The aim of the present experimental trail was to; (1) evaluate the evaporative cooling system (fan-pad system) in commercial laying hens housing during summer of 2014, (2) determine experimentally the influence of water flow regimes applied to cooling pads on THI and VPD, and (3) study the production, weight of eggs and body weight during experimental period. 


\section{MATERIALS AND METHODS}

\section{Materials}

The following sections describe the materials that functioned in the present experimental work. These materials such as laying-hens house, laying-hens and evaporative cooling systems.

\section{House of laying-hens and equipment}

The experimental work was carried out from June to August 2014 in a private commercial closed housing of laying hens, orientated in N-S direction, and located at the eastern area of coastal Delta, Egypt (latitude angle of $31.05^{\circ} \mathrm{N}$, longitude angle of $31.37^{\circ} \mathrm{E}$, and mean altitude above sea level of $14 \mathrm{~m}$ ). Three identical laying-hens houses are functioned during the experimental work. The geometric characteristics of each house are as follows: height, $3.25 \mathrm{~m}$, length, $46 \mathrm{~m}$, width $10 \mathrm{~m}$, floor surface area $460 \mathrm{~m}^{2}$, and volume $1495 \mathrm{~m}^{3}$. The foundations and plastered walls of the poultry are made of $15 \mathrm{~cm}$ thick concrete. The ceiling of the house is covered by $15 \mathrm{~cm}$ thick reinforced concrete. It is important to arrange all equipment so that the tasks associated with management, such as feeding, drinking and egg collection can be carried out easily. Mechanical feeder system is commonly functioned for feeding the laying hens. Twenty-two hand drinkers (5 litres capacity, each) are also evenly distributed inside the house for drinking hens by the rate of one hand drinker for 100 birds during the first ten days of rearing. For quick and easily collection of eggs two rows of nests are arranged along the inside walls. Due to the hen yard is a cheaper version of the deep litter house, a layer of rice husks is used as the bedding.

\section{Evaporative cooling system}

Outdoor air was forced through $14.4 \mathrm{~m}^{2}$ face area of $15 \mathrm{~cm}$ thick cellulose cooling pads situated on the middle of the northern vertical wall of the house (side toward the prevailing winds) as shown in Fig. (1). Sixteen corrugated cellulose pads, each having gross dimensions of 60 $\mathrm{cm}$ wide and $150 \mathrm{~cm}$ high are functioned. These corrugated cellulose pads permit $75 \mathrm{~m} / \mathrm{min}$ air speed. A polyvinyl chloride (PVC) pipe (12.5 $\mathrm{mm}$ diameter) was suspended immediately above the pads. Holes were drilled in a line about $5 \mathrm{~cm}$ apart along the top side, and the end of this 
pipe was capped. A baffle was placed above the water pipe to prevent any leaking of water from the system. A sump (gutter) was mounted under the pads to collect the water and return it into the water tank (300 litres capacity) from which it can be recycled to the pads by the water pump. After crossing the pads, air travels a $46 \mathrm{~m}$ distance before being exhausted by four extracting fans located on the opposite side wall (southern wall). Each extracting fan generated an airflow rate of about 34 $000 \mathrm{~m}^{3} / \mathrm{h}$ under $2.5 \mathrm{~mm}$ static pressure. The evaporative cooling system was continuously operated when the indoor air temperature of the house reached to $30^{\circ} \mathrm{C}$. The air temperature inside the house, at a height of about $1.8 \mathrm{~m}$ above floor level (monitor), was controlled by an on-off controller (differential thermostat) to initiate ventilating at $30^{\circ} \mathrm{C}$ and interrupt it at $29^{\circ} \mathrm{C}$. In reality, the Egyptian growers belief that, the beneficial effect of lowering indoor air relative humidity can exceed the negative effect of increased indoor air temperature above $25^{\circ} \mathrm{C}$.

\section{Laying hens}

Three identical closed commercial houses of laying hens each is occupied with total complement of 2200 birds for producing egg by a rate of 1900 eggs per day. Three different water flow rates $(60,70$, and $80 \mathrm{l} / \mathrm{min}$ ) were used to pass through the cooling pads of a complete evaporative cooling system functioned with three identical houses. Relatively large birds $(2.250 \mathrm{~kg})$ were assumed and other parameters were selected to represent current laying hens housing as given in Table (1). The mass rate of ventilation represented a typical maximum ventilation rate for such housing $(45.33 \mathrm{~kg} / \mathrm{s})$. While ventilation rate in moderate weather and at night is not typically at the maximum value, this simple approach was taken to reduce the number of computations while providing extreme occurrences of temperature-humidity index (THI).

\section{Measurements}

Air temperature and relative humidity were measured and recorded at three different locations inside the house of laying hens: one just next to the cooling pads, one mid-way down-stream (denoted middle), and the third one just prior to the extracting fans as shown in Fig. (2). The temperature probes were Pt 100 resistors with 3 wires mounting with an 
accuracy of $\pm 0.3 \%$. The air relative humidity probes (Rotronic, UK) were polymer capacitors that provided a frequency response transformer into a 4-20 mA signal with a rated accuracy of about $\pm 2 \%$. Dry-bulb temperature and relative humidity of outdoor air were measured using Digital Hygro-thermometer anemometer with an accuracy of $\pm 0.01 \mathrm{~m} / \mathrm{s}$. The wet-bulb temperature of the outdoor air was determined at a specific dry-bulb temperature and relative humidity of outdoor air using the psychrometric program.

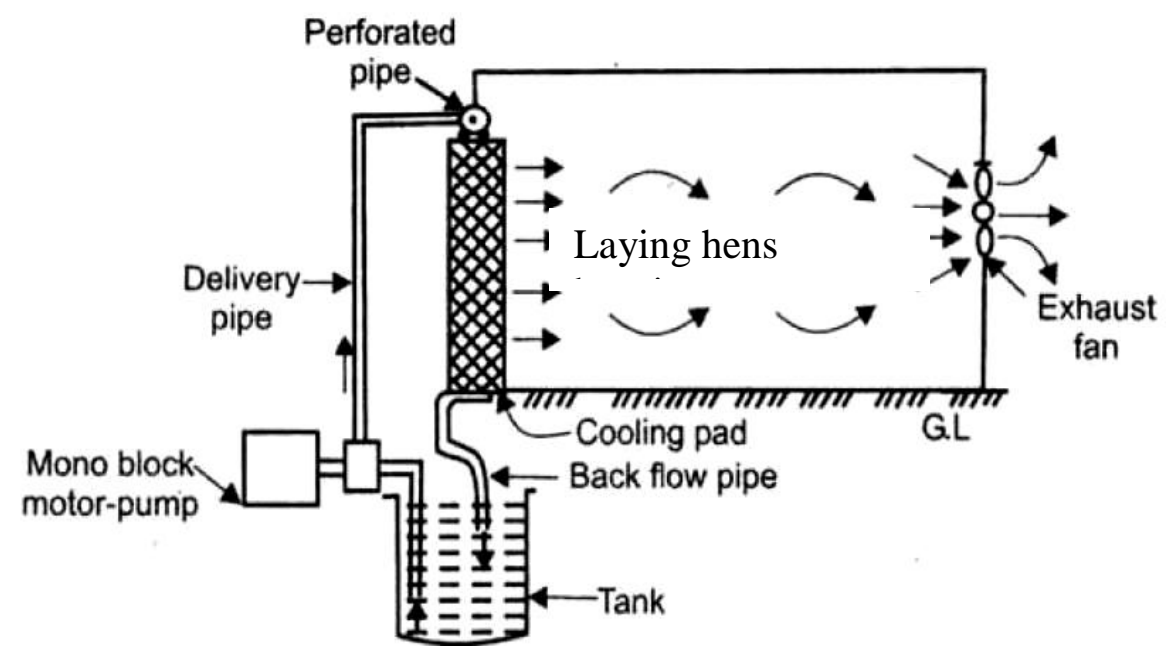

Fig. (1): Schematic diagram of evaporative cooling system based on fanpad system.

Table (1): Parameters used for laying-hens housing thermal model

\begin{tabular}{|l|c|}
\hline Parameter & Value \\
\hline Number of birds & 2200 \\
Mass of one bird & $2.250 \mathrm{~kg}$ \\
Birds age & 150 days \\
Stet-point $\left(\mathrm{T}_{\mathrm{ai}, \mathrm{sp}}\right)$ & $29^{\circ} \mathrm{C}$ \\
Evaporative cooling set-point $\left(\mathrm{T}_{\mathrm{ai}}\right.$, evap. $)$ & $30^{\circ} \mathrm{C}$ \\
Maximum ventilation rate $\left(\mathrm{m}_{\mathrm{a}}\right)$ & $45.33 \mathrm{~kg} / \mathrm{s}$ \\
Mass flow rates of water $\left(\mathrm{m}_{\mathrm{w}}\right)$ & $1.0,1.1667$, and $1.3333 \mathrm{~kg} / \mathrm{s}$ \\
\hline
\end{tabular}


The air temperatures just leaving the cooling pads and exhausting from the laying hens house through the extracting fans were also measured and recorded. Simultaneously to the measurements of microclimatic (inside) and macroclimatic (outside) variables were recorded. Measurements of all above sensors were centralized on a data-logger system (DL3000, Delta-T device, UK) with 30 seconds time period, and averaged out on a 30 minutes time scale before being processed.

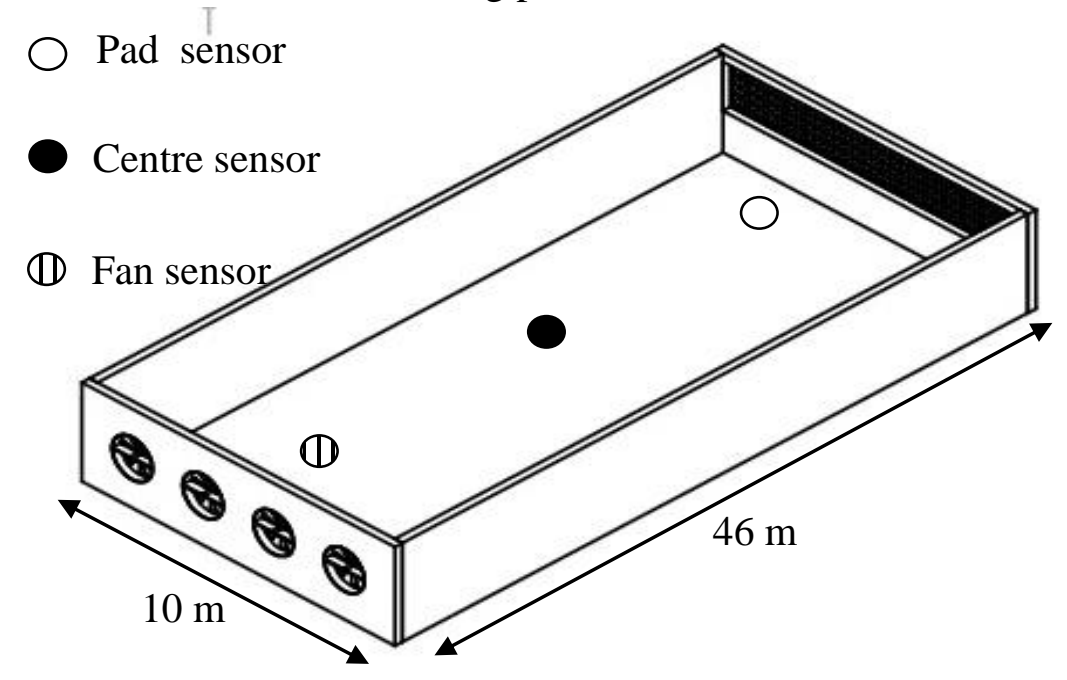

Fig. (2). A schematic diagram the experimental of laying-hens house to be cooled, temperature and relative humidity sensors arrangement inside housing.

\section{Methods}

The experimental work was carried out to determine the effect of water flow rate on the efficiency of the evaporative cooling system (fan-pad system) and the heat energy being absorbed during the cooling process. Three different levels of water flow rate $(60,70$, and $801 / \mathrm{min})$ were used during June to August 2014. Airflow measurements were taken at selected diagonal locations across each pad and the velocity average of air passing through the cooling pads was calculated. The efficiency of evaporative cooling system is namely associated with the cooling effect, wet-bulb depression, rate of heat transfer from air to water, and water consumption in evaporation process.. The cooling efficiency $(\eta, \%)$ can be computed in terms of the cooling effect (denominator) and the wet- 
bulb depression (numerator) using the following equation (Kittas et al., 2001; Al- Sulaiman, 2002; ASHRAE, 2005):

$$
\eta=\frac{T_{a o}-T_{p a d}}{T_{a o}-T_{a o w}} \times 100, \quad \%
$$

Where, $\mathrm{T}_{\mathrm{ao}}$, is the outdoor air temperature in ${ }^{\circ} \mathrm{C}, \mathrm{T}_{\mathrm{pad}}$, is the cooled air just leaving the cooling pads in ${ }^{\circ} \mathrm{C}$, and, $\mathrm{T}_{\text {aow }}$, is the wet-bulb air temperature of the outdoor in ${ }^{\circ} \mathrm{C}$. The rate of heat energy removal from the laying hen's house can be calculated from the following equation:

$$
\mathrm{Q}=\mathrm{m}\left(\mathrm{h}_{\mathrm{pad}}-\mathrm{h}_{\mathrm{ex}}\right), \mathrm{kWh}
$$

Where, $\mathrm{m}$, is the mass flow rate of exhausting air in $\mathrm{kg} / \mathrm{s}, \mathrm{h}_{\mathrm{pad}}$, is the enthalpy of air just leaving the cooling pads, and, $h_{e x}$, is the enthalpy of exhausting air in $\mathrm{kJ} / \mathrm{kg}$.

The total amount of moisture addition to the saturated air after cooling by evaporative process $(\mathrm{W})$ in $\mathrm{kg} / \mathrm{h}$, is computed based on the humidity ratio of air after $\left(\mathrm{W}_{2}\right)$ and before passing through the cooling pads $\left(\mathrm{W}_{1}\right)$ in $\mathrm{kg}_{\mathrm{w}} / \mathrm{kga}$, and the mass flow rate of cooled air (M) in $\mathrm{kg} / \mathrm{h}$ by the following equation:

$$
\mathrm{W}=\mathrm{M}\left(\mathrm{W}_{2}-\mathrm{W}_{1}\right), \quad \mathrm{kg} / \mathrm{h}
$$

There are limitations to any particular measure of livestock heat stress. For example, a temperature humidity index (THI) for laying hens was developed from egg production data at different environments (Gates et al., 1991). Any environment which produces the same value of THI is presumably equivalent in terms of egg production, but not necessarily meat production or animal thermal comfort. Daily THI values were determined for the experimental period using the equation which was described by Gates et al. (1995):

$$
\mathrm{THI}=0.6 \mathrm{~T}_{\mathrm{ai}, \mathrm{db}}+0.4 \mathrm{~T}_{\mathrm{ai}, \mathrm{wb}},{ }^{\circ} \mathrm{C}
$$

Where, $\mathrm{T}_{\mathrm{ai}}$ db , is the indoor dry-bulb air temperature in ${ }^{\circ} \mathrm{C}$ and, $\mathrm{T}_{\mathrm{ai}}$, wb, is the indoor wet-bulb air temperature in ${ }^{\circ} \mathrm{C}$. It has been used to assess laying hens production in response to heat stress. Within the limitations 
of a particular heat stress index, its application as a quantitative measure to evaluate alternate environmental control strategies is useful tool.

To express the synergistic effects of indoor dry-bulb air temperature $\left(\mathrm{T}_{\mathrm{ai}}\right.$, $\mathrm{db})$ and indoor dew-point air temperature $\left(\mathrm{T}_{\mathrm{ai}, \mathrm{dp}}\right)$, vapour pressure deficit of the indoor air $\left(\mathrm{VPD}_{\text {air }}\right)$ was functioned and computed according to the following equation (ASHREA, 2005):

$$
\mathrm{VPD}_{\text {air }}=\mathrm{P}_{\mathrm{ws}} \mathrm{x}(1-\mathrm{RH}), \quad \mathrm{kPa}
$$

Where, $\mathrm{P}_{\mathrm{ws}}$, is the saturation vapour pressure at $\left(\mathrm{T}_{\mathrm{ai}} \mathrm{db}\right)$ in $\mathrm{kPa}$, and, $\mathrm{RH}$, is the indoor air relative humidity in decimal. For $0^{\circ} \leq \mathrm{T}_{\mathrm{ai}} \mathrm{db} \leq 200^{\circ} \mathrm{C}$, $\mathrm{P}_{\mathrm{ws}}$ can be calculated from the equation(ASHREA, 2005):

$\mathrm{P}_{\mathrm{ws}}=\exp \left[\mathrm{C}_{1} / \mathrm{T}+\mathrm{C}_{2}+\mathrm{C}_{3} \mathrm{~T}+\mathrm{C}_{4} \mathrm{~T}^{2}+\mathrm{C}_{5} \mathrm{~T}^{3}+\mathrm{C}_{6} \ln (\mathrm{T})\right]$

Where, $\mathrm{T}$, is the dry-bulb temperature in Kelvin, and the constants are as follows:

$$
\begin{array}{lll}
\mathrm{C}_{1}=-5.8002206 \mathrm{E}+03 & , & \mathrm{C}_{2}=1.3914993 \mathrm{E}+00 \\
\mathrm{C}_{3}=-4.8640239 \mathrm{E}-02 & , & \mathrm{C}_{4}=4.1764768 \mathrm{E}-05 \\
\mathrm{C}_{5}=-1.4452093 \mathrm{E}-08 & , & \mathrm{C}_{6}=6.5459673 \mathrm{E}+00
\end{array}
$$

\section{RESULTS AND DISCUSSION}

Animals and poultry dissipate body heat through four basic mechanisms of heat and mass transfer: conduction, convection, radiation, and evaporation. The first three mechanisms make up the sensible heat loss pathway, which is driven by the air temperature gradient between the animal or poultry and its surroundings. In comparison, evaporative heat loss is driven by the vapour pressure deficit. When indoor air temperature approaches or exceeds body temperature, evaporation becomes the only pathway for an animal and poultry to dissipate heat to maintain homeostasis. Unfortunately some domestic animals, chickens do not have sweat glands, which adversely affect their ability to lose heat by skin surface evaporation. Although the respiratory system tract can dissipate some heat, depressed daily body weight gain and rate of eggs production and increased mortality rates. Therefore, air-cooling is desirable in many areas of Egypt in order to prevent chickens heat stress. Several evaporative cooling systems have been explored to cool poultry at high 
air temperatures in order to relieve heat stress of birds. Even areas of high air relative humidity ( $\mathrm{RH})$, the beneficial effect of lowering air temperature can exceed the negative effect of increased $\mathrm{RH}$.

\section{The saturation efficiency of pad cooling system}

The saturation efficiency that indicates evaporative cooling efficiency for various different flow rate values throughout operating period as shown in Fig.(3). The daily averages evaporative cooling efficiency during the experimental period for the three different water flow rates $(60,70$, and $801 / \mathrm{min}$ ), respectively, were $76.2 \%, 78.0 \%$, and $77.5 \%$. The previous cooling efficiency values associated with cooling effect during experimental period. The best time to calculate the maximum cooling effect performance of the evaporative cooling system was at noon and afternoon period. This always occurred when the wet and dry bulb temperatures were at the peak values because solar radiation and outside temperature was high at those times. As the cooling effect is increased, the higher cooling efficiency achieved. The maximum cooling efficiency was achieved at noon or afternoon when the difference between outdoor and indoor air temperatures increased. The cold air temperatures just leaving the cooling pads during the experimental period were lowered by $7.1,8.5$, and $8.3^{\circ} \mathrm{C}$ for those water flow rates, respectively. Consequently, the best water flow rate in which the highest cooling efficiency achieved was $70 \mathrm{l} / \mathrm{min}$. This result is in agreement with that published by Nelson (2006), when stated that the best water flow rate passing through the cooling pads is $7.51 / \mathrm{min}$ per length of cooling pads the length of cooling pads is $9.6 \mathrm{~m}$. The optimal water flow rate is 72 $1 /$ min. Effectiveness of the evaporative cooling system based on fan-pad system under different circumstances was investigated in particular for the hottest days during the summer season (June to August of 2014).

During this period, the control board according to the optimal set point temperature $\left(29^{\circ} \mathrm{C}\right)$ automatically operated the fan-pad system. The first set of data was collected for computing the efficiency of evaporative cooling system at three different levels of water flow rate, from measurements performed during the experimental period. The daily averages hourly climatic conditions were selected for the calculation. 


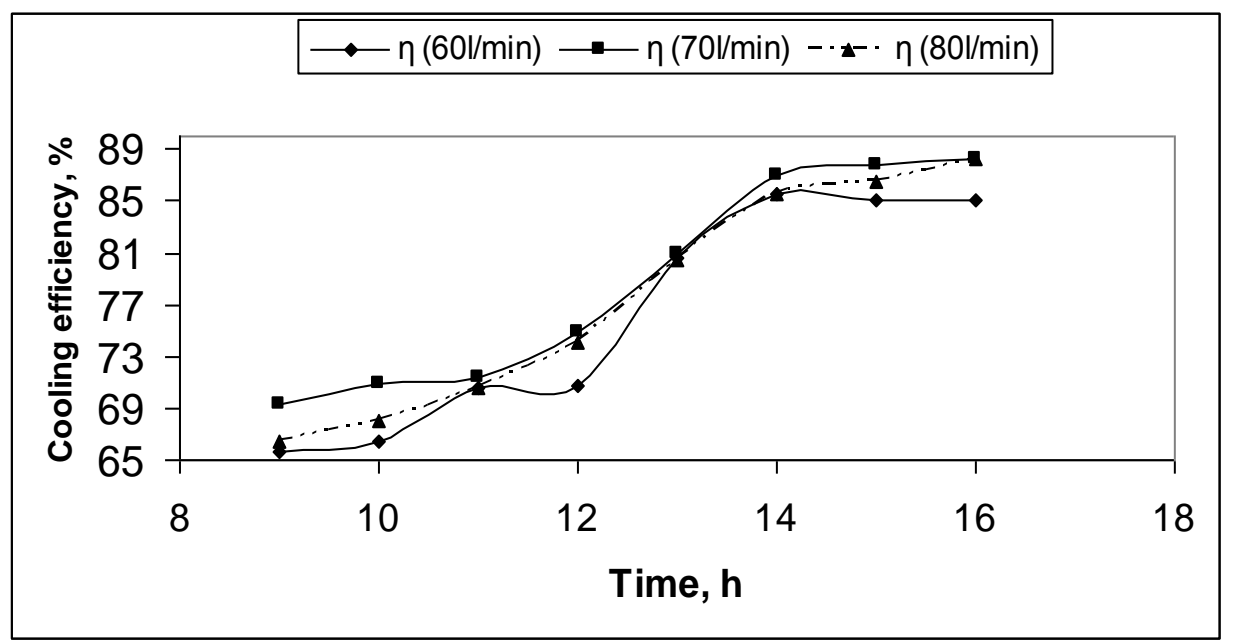

Fig. (3). Evaporative cooling efficiency $(\eta)$ for three different water flow rates during the experimental period.

The daily average macroclimatic conditions (outside climatic variables) during June, July, and August months (average over the period 9.00 to 16.00 local time) are summarized and listed in Table (2). The higher values of cooling efficiencies was achieved on August month because this month had a lowest average outdoor air relative humidity than the other tested months resulting in increasing the air temperature difference between entering and leaving the cooling pads. This indicator clarified that the outdoor weather conditions were strongly affected the effectiveness of evaporative cooling system.

The daily averages weight of moisture added to the indoor air during the experimental period for the three different water flow rates $(60,70$, and $80 \mathrm{l} / \mathrm{min}$ ), respectively, were $305.9,328.7$, and $352.2 \mathrm{~g}_{\mathrm{w}} / \mathrm{kg}_{\mathrm{a}}$. Therefore, the water flow rate $80 \mathrm{l} / \mathrm{min}$ increased the water added to the indoor air of laying-hens house by $46.3 \mathrm{~g}_{\mathrm{w}} / \mathrm{kg}_{\mathrm{a}}$ or $15.1 \%$ as compared with the water flow rate $601 / \mathrm{min}$. While, the water flow rate $701 / \mathrm{min}$ increased the water added to the house of laying-hens by $22.8 \mathrm{~g}_{\mathrm{w}} / \mathrm{kg}_{\mathrm{a}}$ or $7.5 \%$ as compared with the water flow rate $60 \mathrm{l} / \mathrm{min}$. 
Table (2): Daily average macroclimatic conditions and effectiveness of the evaporative cooling system during the experimental period

\begin{tabular}{|l|l|l|l|l|}
\hline Month & $\mathrm{T}_{\mathrm{ao}},{ }^{\circ} \mathrm{C}$ & $\mathrm{RH}_{o}, \%$ & $\mathrm{~T}_{\mathrm{aow}},{ }^{\circ} \mathrm{C}$ & $\eta, \%$ \\
\hline June & 31.5 & 50.1 & 23.4 & 77.4 \\
SD & \pm 1.2 & \pm 2.8 & \pm 1.6 & \pm 1.5 \\
\hline July & 31.9 & 52.6 & 24.2 & 75.6 \\
SD & \pm 1.0 & \pm 2.0 & \pm 1.4 & \pm 1.6 \\
\hline August & 31.3 & 49.2 & 23.0 & 79.5 \\
SD & \pm 1.3 & \pm 2.6 & \pm 1.3 & \pm 1.8 \\
\hline
\end{tabular}

Surface wetting by water flow rate $60 \mathrm{l} / \mathrm{min}$ had some advantages over the other water flow rates $(70$ and $801 / \mathrm{min}$ ) in that it provided dried ventilation air because of less water added to the indoor air. However, the beneficial effect of lowering indoor air temperature can exceed the negative effect of increase moisture content.

The experimental data revealed that, the evaporative cooling system was able to keep the indoor air temperature lower than $29^{\circ} \mathrm{C}$ in all circumstances. In addition, the air temperature just leaving the cooling pads stayed $8^{\circ} \mathrm{C}$ below outdoor air temperature, even during hot afternoons (temperatures higher than $35^{\circ} \mathrm{C}$ ), due to the low levels of outdoor air relative humidity, high levels of air temperature, and accordingly the high efficiency of the evaporative cooling system (at and around $80 \%$ ). The evaporative cooling efficiency was functioned to examine the relationships between the cooling efficiency $(\eta)$ and both of, the cooling effect $\left(\mathrm{C}_{\mathrm{E}}\right)$ and wet-bulb depression $\left(\mathrm{W}_{\mathrm{D}}\right)$ for the three different water flow rates. Multiple regression analysis revealed that the evaporative cooling efficiency for the three flow rates was strongly affected by the cooling effect and wet-bulb depression. The multiple regression equations obtained were:

$$
\begin{aligned}
& \eta(60 \mathrm{l} / \mathrm{min})=16.0958(\mathrm{CE})-2.8027\left(\mathrm{~W}_{\mathrm{D}}\right) \quad \mathrm{R}^{2}=0.9495 \\
& \eta(70 \mathrm{l} / \mathrm{min})=16.9034(\mathrm{CE})-2.3123\left(\mathrm{~W}_{\mathrm{D}}\right) \quad \mathrm{R}^{2}=0.9957 \\
& \eta(80 \mathrm{l} / \mathrm{min})=17.1823(\mathrm{CE})-3.8440\left(\mathrm{~W}_{\mathrm{D}}\right) \quad \mathrm{R}^{2}=0.9945
\end{aligned}
$$

The combined correlation coefficients for these parameters together for 
the three different water flow rates were 0.9744, 0.9978, and 0.9972, respectively.

Due to the long air stream path through the house of laying hens (46 m), thermal gradients were observed in its direction. The measured indoor air temperatures just leaving the cooling pads $\left(\mathrm{T}_{\mathrm{pad}}\right)$, at the middle of the laying hens house $\left(\mathrm{T}_{\text {center }}\right)$, and at the extracting fan $\left(\mathrm{T}_{\text {fan }}\right)$ as compared with the outdoor air temperature $\left(\mathrm{T}_{\text {out }}\right)$ during the experimental period are summarized and listed in Table (3). These data recorded for an 8-hour period represented the daylight-time when the evaporative cooling system was operated. Gradual indoor air temperature rise from the cooling pads $\left(24.6^{\circ} \mathrm{C}\right)$ to the middle $\left(27.0^{\circ} \mathrm{C}\right)$, reaches $3.7^{\circ} \mathrm{C}$ at and around noon when the warm air (sensible heat from the body surface of birds and metabolic process) ascended due to thermal buoyancy forces.

The indoor air temperatures of the laying-hens house varied from 4 to $7^{\circ} \mathrm{C}$ for 60 and $70 \mathrm{l} / \mathrm{min}$ water flow rate treatments, while ranged from 4 to $6^{\circ} \mathrm{C}$ for $80 \mathrm{l} / \mathrm{min}$ water flow rate manipulate. In addition, the obtained data indicate that the outdoor air temperatures between 12:00 $\mathrm{h}$ and 14:00 $\mathrm{h}$ were extremely high and the relative humidity $(\mathrm{RH})$ was greatly reduced. The air temperature inside the shelter was significantly lower and the RH was higher than the outside condition.

Table (3): Indoor air temperature variations in different positions in the laying-hens house

\begin{tabular}{|c|c|c|c|}
\hline Month & $\mathrm{T}_{\mathrm{pad}},{ }^{\circ} \mathrm{C}$ & $\mathrm{T}_{\text {center }},{ }^{\circ} \mathrm{C}$ & $\mathrm{T}_{\mathrm{fan}},{ }^{\circ} \mathrm{C}$ \\
\hline June & 24.4 & 27.0 & 28.6 \\
\hline (SD) & $( \pm 0.7)$ & $( \pm 1.1)$ & $( \pm 1.3)$ \\
\hline July & 25.3 & 27.7 & 29.3 \\
\hline (SD) & $( \pm 0.8)$ & $( \pm 1.0)$ & $( \pm 1.2)$ \\
\hline August & 24.0 & 26.4 & 28.2 \\
\hline (SD) & $( \pm 0.9)$ & $( \pm 1.2)$ & $( \pm 1.4)$ \\
\hline
\end{tabular}

The indoor air temperatures in different positions; just leaving the cooling pads, at the middle of house, and at the extracting fans were allows lower than the outdoor air temperatures throughout the daylight- 
time. The center temperatures had higher values than the cooling pads temperatures because the sensible heat emitted from hens increase the temperature from distance between the cooling pads and the center. All treatments were taken the same trend between the outdoor and indoor air temperatures at the center as well as the temperature difference between outdoor air and cooling pads.

The heat energy removal from the laying-hens house varied from hour to hour and water flow rate to another during the experimental period as revealed in Fig.(4). The greatest amount of heat energy removal was achieved with water flow rate of $80 \mathrm{l} / \mathrm{min}$ as compared with the other two flow rates (60 and 70 1/min)

The weight averages, maximum and minimum values of indoor and outdoor air temperatures, and relative humidity data measured during experimental period are listed in Table (4). For the duration of the experimental work, the daily average values indoor air temperature and relative humidity were $28.2^{\circ} \mathrm{C}$ and $64.3 \%$, respectively. The daily averages outdoor air temperature and relative humidity, respectively, were $31.8^{\circ} \mathrm{C}$ and $50.6 \%$ during the study period in region conditions.

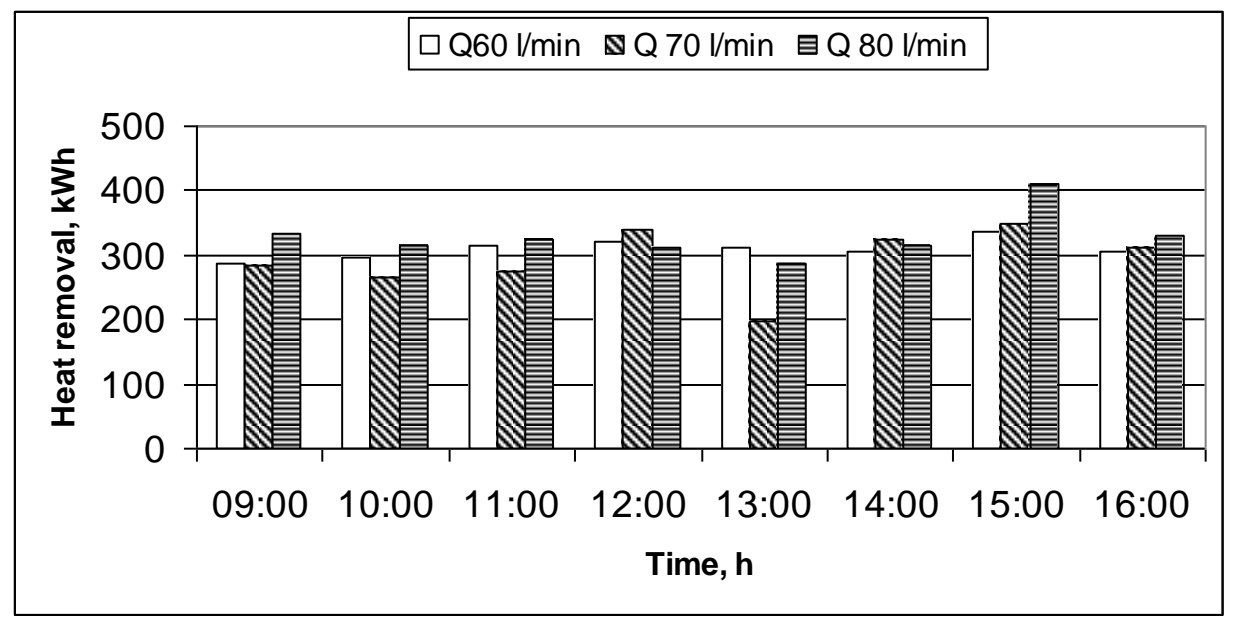

Fig. (4). Heat energy removal during day-light time for three different water flow rates 
Almost sufficiency of indoor environmental conditions, the differences between mean and minimum, maximum indoor air temperature and relative humidity are considered to be an important indictor.

Table (4): Indoor and outdoor environmental conditions measured during study period.

\begin{tabular}{|c|c|c|c|c|}
\hline Parameters & Max. & Min. & Mean & SD \\
\hline Indoor air temperature, ${ }^{\circ} \mathrm{C}$ & 30.8 & 26.3 & 28.5 & \pm 1.22 \\
\hline Outdoor air temperature, ${ }^{\circ} \mathrm{C}$ & 35.1 & 30.2 & 31.8 & \pm 0.85 \\
\hline Indoor air relative humidity, $\%$ & 80.5 & 59.1 & 64.3 & \pm 4.10 \\
\hline Outdoor air relative humidity, \% & 70.1 & 34.7 & 50.6 & \pm 4.70 \\
\hline Temperature-humidity index (THI), ${ }^{\circ} \mathrm{C}$ & 29.7 & 24.0 & 26.0 & \pm 1.00 \\
\hline Vapour pressure deficit (VPD), $\mathrm{kPa}$ & 1.388 & 0.859 & 1.178 & \pm 0.21 \\
\hline
\end{tabular}

In laying hens house, the differences between mean and minimum, maximum indoor air temperature were 2.2 and $2.7^{\circ} \mathrm{C}$ while for air relative humidity it were 5.2 and $26.2 \%$, respectively. Lin et al. (2006) reported that, theindoor air temperatures exceed $30^{\circ} \mathrm{C}$, cause to heat stress for laying hens and then the laying hens pant to release heat from her bodies. Feed consumption rate of laying hens decrease, egg production diminishes and egg size and shell qualities deteriorate in indoor air temperature between 29 and $32^{\circ} \mathrm{C}$ (Mashaly et al., 2004, Kilic and Simsek, 2013). Ugurlu et al. (2002) stated that, optimum indoor air relative humidity should be ranged between 65 and $70 \%$ for laying hens. Consequently, according to the data obtained during the experimental period under specific circumstances, indoor environmental conditions of the laying hen's house $\left(28.5^{\circ} \mathrm{C}\right.$ and $\left.64.3 \%\right)$ are quite sufficient to supply temperature and humidity demands of laying hens for optimal level of production.

When the temperature humidity index (THI) values increased from 25$29^{\circ} \mathrm{C}$, heat stress occurred and reduced the egg production rate by $25 \%$. According to the THI values calculated inside the house of laying hens and the weight mean of THI value was found to be $26^{\circ} \mathrm{C}$ during the experimental period as listed in Table (4), therefore, the THI was not at danger level for heat stress. Also, vapour pressure deficit (VPD) values 
computed daily for the house of laying hens and weight mean value was found as $1.178 \mathrm{kPa}$ according to the data measured (Table 4). The vapour pressure deficit values during the experimental period showed that the laying hens were not stressed as the indoor environmental conditions were comfortable for all birds. When the temperature humidity index (THI) values increased from $25-29^{\circ} \mathrm{C}$, heat stress occurred and reduced the egg production rate by $25 \%$. According to the THI values calculated inside the house of laying hens and the weight mean of THI value was found to be $26^{\circ} \mathrm{C}$ during the experimental period as listed in Table (4), therefore, the THI was not at danger level for heat stress.

The vapour pressure deficit (VPD) values computed daily for the house of laying hens and weight mean value was found to be $1.178 \mathrm{kPa}$ according to the data measured (Table 4). The vapour pressure deficit values during the experimental period showed that the laying hens were not stressed as the indoor environmental conditions were comfortable for all birds. The vapour pressure deficit (VPD) was used to examine the relationships between the VPD and both of, the indoor air temperature $\left(\mathrm{T}_{\mathrm{ai}}\right)$ and indoor air relative humidity $\left(\mathrm{RH}_{\mathrm{i}}\right)$ for the three different water flow rates. Multiple regression analysis revealed that the vapour pressure deficit for the three flow rates was strongly affected by the indoor air temperature and relative humidity. The multiple regression equations obtained were:

$$
\begin{aligned}
& \operatorname{VPD}(60 \mathrm{l} / \mathrm{min})=0.0120\left(\mathrm{~T}_{\mathrm{ai}}\right)-3.412\left(\mathrm{RH}_{\mathrm{i}}\right) \mathrm{R}^{2}=0.9920 \\
& \operatorname{VPD}(70 \mathrm{l} / \mathrm{min})=0.0112\left(\mathrm{~T}_{\mathrm{ai}}\right)-2.864\left(\mathrm{RH}_{\mathrm{i}}\right) \mathrm{R}^{2}=0.9931 \\
& \operatorname{VPD}(80 \mathrm{l} / \mathrm{min})=0.0123\left(\mathrm{~T}_{\mathrm{ai}}\right)-3.504\left(\mathrm{RH}_{\mathrm{i}}\right) \mathrm{R}^{2}=0.9930
\end{aligned}
$$

The combined correlation coefficients for these parameters together for the three different water flow rates were 0.9960, 0.9965, and 0.9965, respectively. The converse effect of heat stress was most likely mediated through a reduction in feed consumption, reducing the available nutrients 
for egg production. When the temperature-humidity index (THI) values increased from 25-29, and the vapour pressure deficit (VPD) increased over $2 \mathrm{kPa}$, heat stress occurred resulting in reducing egg production rate and quality of egg. The findings are in agreement with those of Whitehead et al. (1998). Egg production rate is inversely related to high temperature (Mashaly et al., 2004). They found a 36\% loss in hen-day egg production for hens exposed to the constant hot temperature. Franco-Jimenez and Beck (2007) reported that egg production was differentially affected by heat stress. Moreover, egg weight was also inversely affected by increasing temperature-humidity index (THI) values from 27-30 (Kirunda et al., 2001). When indoor air temperature in house of laying-hens was raised from $22-34^{\circ} \mathrm{C}$ for $9 \mathrm{hr}$ per day, average egg weight was dropped $3 \mathrm{~g}$ or $5 \%$ for heat stress group and also hen-day egg production for heat stress group was as low as about 69\% throughout study period (Seven, 2008). Rectal air temperature is a suitable indicator of thermal balance and may be functioned to determine the negative effects of heat stress on egg production of laying hens.

Due to the microclimatic conditions of laying-hens house were at and around the optimal level throughout the experimental period, the conversion fed rate under comfortable indoor conditions was at high level resulting in increasing the body weight of laying-hens from 2.250 $\mathrm{kg}$ to $2.719,2.822$, and $2.797 \mathrm{~kg}$ for the three different water flow rates, respectively, as listed in Table (5). Therefore, the body weight increasing percentage, respectively, was $20.84 \%, 25.42 \%$, and $24.31 \%$ summarized in Table (5). Accordingly, the production rate of fresh egg was increased in all treatments and reached to 798, 859, and 828 eggs/day, respectively, during the experimental period. Mean egg weight and eggshell weight were all increased with all water flow rates during the experimental period (92 days). The average egg weight for the three different water flow rates, respectively, was $64.7,65.8$, and $65.3 \mathrm{~g} / \mathrm{egg}$. Consequently, egg weight was increased by $14 \mathrm{~g}$ (27.61\%), $17 \mathrm{~g}$ (34.84\%), and $16 \mathrm{~g}(32.45 \%)$, respectively as listed in Table (6). 
Table (5): Body weight for the three different flow rates during the experimental period.

\begin{tabular}{|c|c|c|c|}
\hline \multirow{2}{*}{ Age (day) } & \multicolumn{3}{|c|}{ Body Weight (kg) } \\
\cline { 2 - 4 } & $601 / \mathrm{min}$ & $701 / \mathrm{min}$ & $80 \mathrm{l} / \mathrm{min}$ \\
\hline 180 & 2.678 & 2.800 & 2.796 \\
\hline 210 & 2.727 & 2.830 & 2.794 \\
\hline 242 & 2.752 & 3.016 & 2.801 \\
\hline
\end{tabular}

Table (6): Egg weight for the three different flow rates during the experimental period.

\begin{tabular}{|c|c|c|c|}
\hline \multirow{2}{*}{ Age (day) } & \multicolumn{3}{|c|}{ Egg Weight (g) } \\
\cline { 2 - 4 } & $601 / \mathrm{min}$ & $701 / \mathrm{min}$ & $801 / \mathrm{min}$ \\
\hline 180 & 64.3 & 65.5 & 64.3 \\
\hline 210 & 64.8 & 65.8 & 65.5 \\
\hline 242 & 65.1 & 66.1 & 66.2 \\
\hline
\end{tabular}

\section{CONCLUSIONS}

An experimental work was carried out during the summer of 2014 on three identical closed commercial houses of laying hens each was occupied with total complement of 2200 birds for producing egg by a rate of 1900 eggs per day. Three different water flow rates passing through the evaporative cooling system were functioned with the three houses during the summer season of 2014. Based on the obtained results during the experimental work, the evaporative cooling system was able to keep the indoor air temperature lower than $29^{\circ} \mathrm{C}$ in all circumstances. The following conclusions were drawn:

(1) Evaporative cooling system clearly enhances the bird's ability to cope with heat challenge. The best water flow rate passing through the cooling pads was $701 / \mathrm{min}$. 
(2) The indoor air temperature and relative humidity were not exceeded the levels of $30.8^{\circ} \mathrm{C}$ and $80.5 \%$, respectively. While, the mean values were at and around the optimal levels.

(3) The temperature-humidity index (THI) and vapour pressure deficit were not exceeded $29.7^{\circ} \mathrm{C}$ and $1.388 \mathrm{kPa}$, respectively. The weight mean values of THI and VPD during the experimental period were $26.0^{\circ} \mathrm{C}$ and $1.178 \mathrm{kPa}$, respectively, in which provided a comfortable circumstances for all treatments. Accordingly, the birds in the three houses were not stressed during the summer season.

(4) The egg production rate, egg weight, and eggshell increased during the experimental period and were at the optimal level.

(5) Accordingly, management strategies are mainly needed to minimize heat stress and attain optimal poultry productivity for monitored layer house.

\section{REFERENCES}

Al- Sulaiman, F. (2002) "Evaluation of the performance of local fibers in evaporative cooling" Energy Conversion and Management, 43 (16): 2267-2273

ASRAE (2005) "Handbook of fundamentals" American Society of Heating, Refrigerating, and Air Conditioning Engineers, Atlanta, GA 30329

Cerci, Y. (2003) "A new ideal evaporative freezing cycle" International Journal of Heat and Mass transfer, 46: 2967-2974.

Chung, M., Liao, S. ; and Tin, S. (2010) "Characterizing the performance of alternative cooling pad media in thermal environmental control applications" Taiwan 10617, Republic of China.

Costelloea, B. ; and Finn, D. (2003) "Indirect evaporative cooling potential in air-water systems in temperature climates" Energy and Buildings, 35: 573-591. 
Cruz, V. F. ; Perrissinotto, M. ; and Lucas, E. (2006) "Cooling livestock buildings by pad and fan evaporative cooling system (pad cooling) In: Animal housing in hot climates" a Multidisciplinary View (Naas I ed), pp. 37-38, CIGR section II working group in cooperation with Eurageng, Campians, SP- Brazil.

Dağtekin, M. ; Karaca, C. ; and Yildiz, Y. (2009) "Performance characteristics of a pad evaporative cooling system in broiler house in Mediterranean climate" Biosystems Enginnering, I03: 100-104

Darwesh, M.; Abouzaher, S ; Fouda, T and Helmy, M. (2009) "Effect of using pad manufactured from agricultural residues on the performance of evaporative cooling system" Jordan Journal of Agricultural Sciences, 5(2): 111-127.

Dzivama, A. U ; Bindir, U. B ; and Aboaba, F.O. (1999) "Evaluation of pad materials in construction of active evaporative cooler for storage of fruits and vegetables in arid environments" Asia, Africa and Latin America, AMA, 30 (3):51-55.

Franco-Jimenez, D. J. ; and Beck, M. M. (2007) "Physiological changes to transient exposure to heat stress observed in laying hens" Poultry Science, 86: 538-544.

Gates, R. S.; Usry, J. L.; Nienaber, J. A.; Turner, L. W. and Bridges, C. (1991) "An optimal misting method for cooling livestock housing" Transactions of the ASAE, 34(5):2199-2206.

Gates, R. S.; Zhang, H.; Colliver, D. G. and Overhults, D. G. (1995) "Regional variation temperature humidity index for poultry housing" Transactions of the ASAE, 38 (1): 197-205

Gunhan, T. ; Demir, V. ; and Yagcioglu, A. K. (2007) "Evaluation of the suitability of some local materials as cooling pads" Biosystems Engineering, 96(3):369-377

Kilic, L. ; and Simsek, E. (2013) "The effects of heat stress on egg production and quality of laying hens" J. of Animal and Veterinary Advances, 12 (1): 42-47. 
Kirunda, D. F. ; Scheideler, S. E. ; and McKee, S. R. (2001) "The efficacy of vitamin E (DL-alpha-tocophery1 acetate) supplementation in hen diets to alleviate egg quality deterioration associated with high temperature exposure" Poultry Science, 80: 1378-1383.

Kittas, C.; Bartzanas, T. and Jaffrin, A. (2001) " Greenhouse evaporative cooling: Measurement and data analysis. Transactions of the ASAE, 44(3): 683-689.

Kittas, C.; Bartzanas, T. ; and Jaffrin, A.(2003) "Temperature gradients in a partially shaded large greenhouse equipped with evaporative cooling pads" Biosystems Engineering, 85(1): 87-94

Liao, C. M and Chiu, K. H. (2002) "Wind tunnel modeling the system performance of alternative evaporative pads in Taiwan region" Building Environment, 37:177-187

Lin, H. ; Jiao, H. C. ; Buyse, J. ; and Decuypre, E. (2006) "Strategies for preventing heat stress in poultry" J. of Worlds Poultry Science, 62: 71-86.

Maheshwari, G. P. ; Al-Ragom, F. ; and Suri, R. K. (2001) "Energy saving potential of an indirect evaporative cooler" Applied Energy, 69: 69-76.

Mashaly, M. M. ; Hendricks, G. L. ; Kalama, M. A. ; Gehad, A. E. ; Abbas, A. O. ; and Patterson, P. H. (2004) "Effect of heat stress on production parameters and immune response of commercial laying hens. Poultry Science, 83: 889-894.

Nelson, P. V. (2006) "Greenhouse Operation and Management" fourth edition, Prentice-Hall, Inc., New Jersey 07632

Pierre, ST. N. R; Cobanov, B. and Schnitkey, G. (2003). Economic losses from heat stress by us livestock industries. J. Dairy sci.86:52-77.

Sansibury, D. ; and Sainsbury, P (2003) "Livestock health and 
housing" fourth edition, Cassell Ltd, London, UK

Sethi, V. P. ; and Sharma, S. K. (2007) "Survey of cooling technologies for worldwide agricultural greenhouse applications" Solar Energy, 81: 1447-1459.

Seven, P. T. (2008) "Effects of dietary Turkish propolis and vitamin C on performance, digestibility, egg production and egg quality in laying hens under different environmental temperatures" J. of Asian Aust. Animal Science, 21: 1164-1170.

Ugurlu, N. ; Acar, B. ; and Topak, R. (2002) "production performance of caged layers under different environmental temperatures" Arch. Geflugelk, 66: 43-46.

Whitehead, C. C. ; Bollengier-Lee, S. ; Mitchell, M. A. ; and Williams, P. E. V. (1998) "Alleviation of depression in egg production in heat stressed laying hens by vitamin E." proceedings of $10^{\text {th }}$ European poultry Conference, June 21-26, Jerusalem, Israel: 576-578.

\section{الملخص العربي}

تأثير نظام التبريد بالتبخير علي البيئة الداخلية لمسكن دجاج بياض مغلق تحت

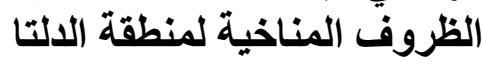

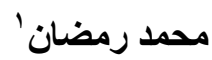

الإجهاد الحر اري في مساكن الدجاج البياض له تأثير ات ضارة يمكن ملاحظة آثاره السلبية علي تطور النمو و الانتاجية وصحة ور احة الطيور.

و هذه الدر اسة تهدف إلي إمكانيـة استخدام نظسام التبريد بالتبخير المباثـر لخفض درجـة حرارة

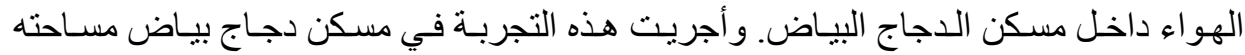

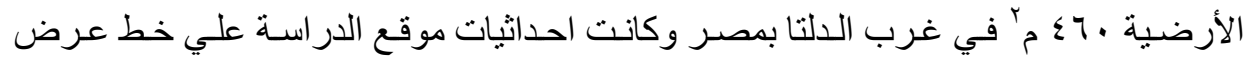

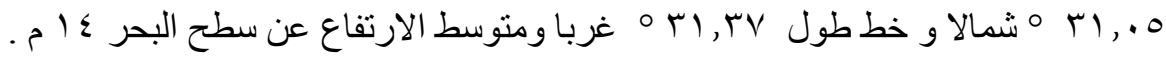
وأجريت التجربة خلال ثلاثة اثهر في صيف ـ ا ـ ب م (شهر يونيو إلي شهر أغسطس) وكانت

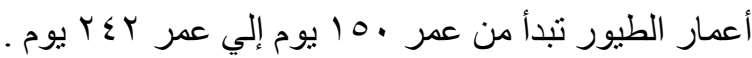

ا مدرس الهندسة الزراعية ـ كلية الزراعة - جامعة طنطا 


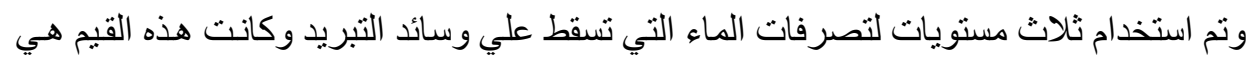

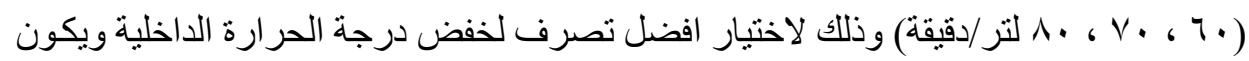

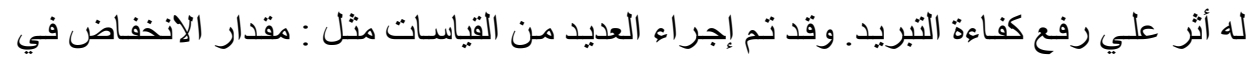

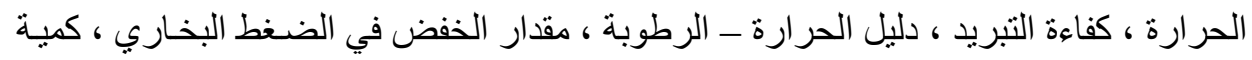

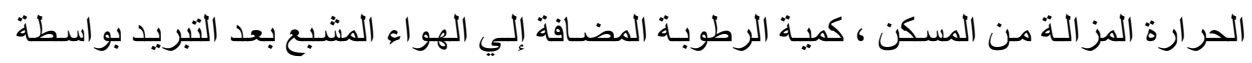

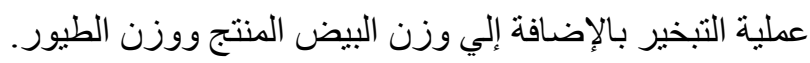

\section{وكانت أهم النتائج ما يلي:}

- - اثتت الدراسة إمكانية استخدام التبريد بالتبخير تحت ظروف الدلتا في مسكن الدجاج

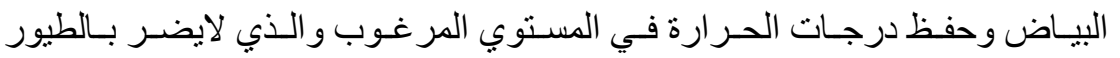

$$
\text { و الإنتاج }
$$

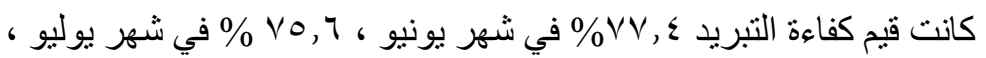

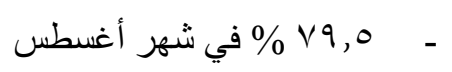

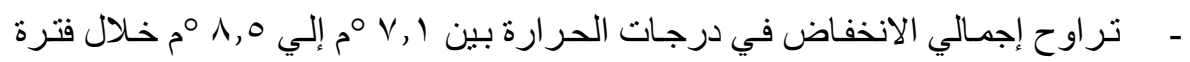

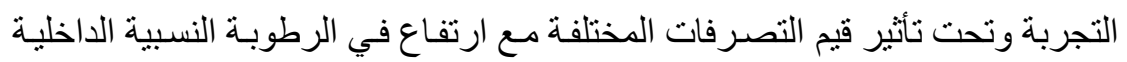

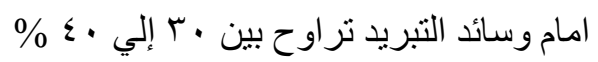

